\title{
Menakar Transaksi Leasing Dalam Tinjaun Hukum Ekonomi Syariah
}

\section{Sumadi}

Sekolah Tinggi Ilmu Ekonomi AAS Surakarta, Indonesia

Email korenpondensi: sumadi@stie-aas.ac.id

Recieved 28-06-2018 | Revised 08-07-2018 | Accepted 24-07-2018

\begin{abstract}
This study aims to measure the lease transaction in the review of sharia economic law. The phenomenon of the practice of leasing transactions in economic activities that develop today is a complicated and complicated issue. Because of its emergence as one of muamalah practices involving a number of parties initially known in advance by the Western world and not found the discussion specifically in the classic books and fatwa ulama. This type of research is a qualitative research using literature study method as the methodology of completion. With the object of research Leasing case seen from the point of view of Islamic economic law, and how the Islamic economy to answer the problem. Leasing Transactions are financing activities in the form of provision of capital goods (eg cars or factory machinery) paid for a certain period of time on a regular basis. From result of research obtained result that related with lease transaction. The form of leasing activity is divided into two, namely the operating lease (ie, lease without option) and financial lease (lease with option rights) Operating lease in fiqih terms equals ijara, while the financial lease practice which has been adjusted to syara criteria 'is called al -The Objective of Muntahia bit Tamlik (IMBT) and the law is halal, while based on the practice and reality in daily life, financial lease shows transaction prohibition, and scholars agree that there is in practice financial lease (conventional leasing).
\end{abstract}

Keywords: Leasing Transaction; Sharia Economic Law; Financing Activities

Saran sitasi: Sumadi, s. (2018). Menakar Transaksi Leasing dalam Tinjauan Hukum Ekonomi Syariah. Jurnal Ilmiah Ekonomi Islam, 4(02), 126-135.doi:http://dx.doi.org/10.29040/jiei.v4i2.262

DOI: http://dx.doi.org/10.29040/jiei.v4i2.262

\section{Pendahuluan}

Fenomena praktik transaksi leasing dalam kegiatan ekonomi yang berkembang dewasa ini merupakan persoalan yang pelik dan rumit. Sebab munculnya sebagai salah satu praktik muamalah yang melibatkan sejumlah pihak pada mulanya dikenal terlebih dahulu oleh dunia Barat dan tidak ditemukan pembahasannya secara khusus dalam kitab-kitab klasik dan fatwa ulama. Untuk sebagian umat Islam, masalah leasing masih merupakan suatu hal yang membingungkan sehingga untuk menemukan dasar hukum leasing dalam Islam, ulama dituntut untuk berusaha menggalinya sendiri dengan berdasarkan pada maqasid asy syar'iyah, sebagaimana dipahami dari al-Qur'an dan hadis. Islam sebagai agama dan ideologi (pandangan hidup), selain mengatur hubungan manusia dengan Allah, Islam juga sangat berkempentingan meletakkan basis-basis etika dan moral dalam hubungan manusia dengan sesama, Islam memiliki konsep yang jelas dalam mengajarkan soal harta, asal harta yang didapatkan dan pendistribusian harta ( Sumadi,2017).

Kegiatan transaksi leasing merupakan kegiatan ekonomi yang belum ada aturannya secara eksplisit baik di dalam al-Qur'an, hadis Nabi Saw, maupun hasil ijtihad ulama terdahulu. Oleh 
karenanya, bila ditinjau dari sudut pandang hukum Islam maka leasing merupakan masalah ijtihadiah, yakni suatu persoalan yang perlu dibahas secara serius dandikaji secara teliti dengan cara mencurahkan segala potensi dan kemampuan yang ada untuk mendapatkan ketetapan hukum yang sesuai. Terlepas dari berbagai konsep para pendahulu mengenai kegiatan sewa menyewa, namun pada kenyataannya konsep-konsep dasar tersebut tetap masih banyak digunakan oleh para ekonom masa sekarang dengan bentuk kegiatan transaksi yang beraneka ragam. Di antara transaksi modern yang memiliki kesamaan dalam beberapa aspek dengan kegiatan sewa menyewa dalam term hukum Islam tersebut adalah transaksi perjanjian leasing (Siamat, 1995).

Jika dilihat dari realitasnya, muamalah jenis ini nampak mengunggulkan pemberi sewa (perusahaan leasing) dibandingkan dengan penyewa. Terlebih-lebih bila pihak pembeli merasa mencicil barang dengan harga 'pembelian'. Di tegah jalan, karena sesuatu hal, ia tidak mampu melunasinya. Akhirnya, barang yang diangankan untuk dimilikinya pada akhir cicilan nanti harus dikembalikan, dan ia hanya menyewa saja. Padahal, tentu saja, harga sewa logisnya lebih kecil dibandingkan dengan harga beli dengan cicilan.Satu hal lagi, persoalan leasing menjadi bertambah bila dalam cicilannya itu melibatkan riba (bunga).

Transaksi leasing secara global ada dua, yaitu operating lease dan financial lease. Operating lease adalah menyewa suatu barang untuk mendapatkan manfaat barang yang disewa, sedangkan kepemilikan barang tetap di tangan pemberi sewa.Adapun financial lease merupakan suatu bentuk sewa dimana kepemilikan barang berpindah dari pihak pemberi sewa kepada penyewa. Bila dalam masa akhir sewa pihak penyewa tidak dapat melunasi sewanya, barang tersebut tetap milik pemberi sewa (perusahaan leasing), akadnya dianggap sebagai akad sewa. Sedangkan bila pada masa akhir sewa pihak penyewa dapat melunasi cicilannya, barang tersebut menjadi milik penyewa.Biasanya penga- lihan pemilikan ini dengan alasan hadiah pada akhir penyewaan, pemberian cuma-cuma, atau janji dan alasan lainnya. Intinya, dalam financial lease terdapat dua proses akad sekaligus : sewa sekaligus beli. Dan inilah sebabnya mengapa leasing bentuk ini disebut sebagai sewa-beli. Istilah leasing, pada umumnya diartikan masyarakat sebagai financial lease atau sewa-beli ini (Kurnia, 1999).

Leasing dalam arti financial lease (sewa beli) adalah akad yang batil, karena bertentangan dengan sabda Rasulullah SAW yang melarang terjadinya dua akad berbeda dalam satu akad. Imam Ahmad meriwayatkan bahwa:

"Rasulullah SAW melarang (kaum muslimin) dua perjanjian dalam satu perjanjian"(nahaa rasulullah 'an shafqatain $f i$ shaqatin) (Taqiyuddin An-Nabhani, AsySyakhsyiah Al-Islamiyah)

Syaikh An-Nabhani menafsirkan, bahwa makna hadits tersebut ialah Rasulullah SAW melarang adanya dua akad pada satu akad saja (wujuudu 'aqdain fi aqdin wahidin). Syaikh AnNabhani mencontohkan dua akad dalam satu akad, misalnya seseorang berkata, "Saya menjual motor ini kepada Anda dengan harga 10 juta rupiah dengan cicilan selama 2 tahun, tetapi bila di tengah jalan Anda tidak dapat melunasinya, maka barang tersebut tetap menjadi milik saya dan uang yang telah Anda berikan kepada saya dianggap uang sewa selama anda menggunakannya." Penelitian ini bertujuan untuk mengetahui bagaimana sudut pandang hukum ekonomi Islam terhadap fenomena transaksi Leasing, yang masih terdapat adanya perbedaan dalam menyikapinya dan bagaimana menyelesaikan permasalahan tersebut.

\section{Tinjauan Teori}

Istilah leasing berasal dari kata lease yang berarti sewa-menyewa. Dalam peraturan perundang-undangan yang berlaku di Indonesia, leasing diistilahkan "sewa guna usaha". Dalam Kepmenkeu No. 1169/KMK.01/1991 tentang Kegiatan Sewa Guna Usaha (Leasing) disebutkan bahwa sewa guna usaha adalah kegiatan 
pembiayaan dalam bentuk penyediaan barang modal (misal mobil atau mesin pabrik) selama jangka waktu tertentu berdasarkan pembayaran secara berkala (Salinan Keputusan Menteri Keuangan Republik Indonesia no: 1169/KMK.01/1991 tentang Sewa Guna Usaha (Leasing) Bab I pasal 1)

Secara umum leasing berarti equipment funding, yaitu pembiayaan peralatan/barang modal untuk digunakan pada proses produksi suatu perusahaan baik secara langsung maupun tidak langsung. Leasing juga berarti pembiayaan perusahaan dalam bentuk penyediaan barang modal dengan pembayaran secara berkala oleh perusahaan yang menggunakan barang modal tersebut, dan dapat membeli atau memperpanjang jangka waktu berdasarkan nilai sisa (Nasution, 2006). Perjanjian leasing tidak hanya sebatas suatu kontrak atau persetujuan sewa yang obyeknya berupa barang modal, dan pihak lessee memiliki hak opsi dengan harga berdasarkan nilai sisa, namun lebih kompleks, karena dalam leasing dapat timbul hak beli, dan hal ini sangat mendekati transaksi jual beli aktiva angsuran dan dapat pula seperti sewa menyewa biasa. Leasing memiliki sejarah yang cukup panjang. Dalam realitasnya, leasing merupakan suatu akad untuk menyewa sesuatu barang dalam kurun waktu tertentu. Kegiatan leasing ini ada dua katagori global, sebagaimana yang dijelaskan dalam Kepmenkeu No 1169/KMK.01/1991 yaitu operating lease dan financial lease. Operating lease merupakan suatu proses menyewa suatu barang untuk mendapatkan hanya manfaat barang yang disewanya, tidak terjadi pemindahan kepemilikan (transfer of title) asset, baik di awal maupun di akhir periode sewa. Sewa jenis pertama ini berpadanan dengan konsep ijarah di dalam syariah (Karim, 2003 ).

Ini tentunya menjadi tantangan bagi sistem ekonomi syariah dalam menjawab permasalahan leasing tersebut, yang menjadi problimatika umat. Walaupun kalau kita melihat di lapangan perkembangan ekonomi syariah masih tertinggal dengan Negara tetangga Malaysia, Perkembangan sistem ekonomi syariah di indonesia sendiri belum sebegitu pesat seperti di negara-negara lain, Secara sederhana, perkembangan itu dikelompokkan menjadi perkembangan industri keuangan syariah dan perkembangan ekonomi syariah non keuangan (Cahyani dan Sumadi, 2015).

\section{Metode Penelitian}

Jenis penelitian ini merupakan penelitian kualitatif dengan pendekatan deskriptif yang menggunakan metode studi pustaka sebagai metodologi penyelesaiannya. Dengan obyek penelitian kasus Leasing dilihat dari sudut pandang hukum ekonomi Islam, dan bagaimana ekonomi Islam menjawab permasalahan tersebut. Menurut Best, seperti yang dikutip Sukardi adalah metode penelitian yang berusaha menggambarkan dan menginterpretasikan objek sesuai dengan apa adanya (Sukardi, 2005 ).

\section{Hasil dan Pembahasan}

\subsection{Sejarah Perkembangan Leasing}

Kegiatan usaha leasing sebagai pembiayaan alternatif non bank memiliki sejarah yang cukup panjang. Meskipun tidak diketahui secara pasti, namun diyakini kegiatan transaksi leasing telah terjadi sejak tahun 2000 SM. Sesuai dengan dokumen, pada awalnya transaksi leasing dilakukan oleh orang-orang Sumeria yang dimulai dari peralatan pertanian, hak-hak penggunaan tanah dan air sampai binatang ternak. Dalam perkembangan berikutnya, banyak ditemukan sistem hukum yang mencantumkan transaksi leasing sebagai salah satu metode pembiayaan. Perjalanan berikutnya pada tahun 1284, di Inggris, usaha leasing diatur dalam sebuah undangundang (common law) dan padatahun 1800an mulai terjadi peningkatan jenis barang yang dapat dijadikan sebagai objek leasing.

Seiring dengan perkembangan di bidang industri pertanian, manufaktur dan transportasi telah membawa banyak peralatan yang memungkinkan untuk dibiayai dengan cara leasing. Selain Inggris, pada tahun 1700-an di Amerika juga telah terjadi kegiatan leasing yang berupa kuda dan kereta. Di Amerika, leasing berkembang secara pesat dengan dilakukannya pemba- 
ngunan jaringan rel kereta api di sebagian besar wilayah. Oleh karena banyak perusahaan pengangkutan atau ekspedisi yang tidak membutuhkan peralatan jangka panjang maka pada tahun 1900-an mulai dibuka pembiayaan jangka pendek dan di akhir kontrak objek leasing dikembalikan kepada perusahaan leasing yang bersangkutan. Sesuai dengan perkembangan ekonomi dan sejalan dengan keinginan para produsen, kegiatan leasing meluas dan tersebar ke berbagai negara dengan pesat, terutama setelah tahun 1950-an (Nur, 2007 ).

Dalam realitasnya, leasing merupakan suatu akad untuk menyewa sesuatu barang dalam kurun waktu tertentu. Kegiatan leasing ini ada dua katagori global, sebagaimana yang dijelaskan dalam Kepmenkeu No 1169/KMK.01/1991 yaitu operating lease dan financial lease. Operating lease merupakan suatu proses menyewa suatu barang untuk mendapatkan hanya manfaat barang yang disewanya, tidak terjadi pemindahan kepemilikan (transfer of title) asset, baik di awal maupun di akhir periode sewa. Sewa jenis pertama ini berpadanan dengan konsep ijarah di dalam syariah (Karim, 2003 ). Adapun financial leasse merupakan suatu bentuk sewa dimana di akhir periode sewa si penyewa diberikan pilihan untuk membeli atau tidak membeli barang yang disewakan. Namun, dalam prakteknya (khususnya di Indonesia) sudah tidak ada hak opsi karena sudah "dikunci" di awal periode. Sehingga jenis akadnya menjadi ganda, yakni bila dalam masa akhir sewa pihak penyewa tidak dapat melunasi sewanya, barang tersebut tetap merupakan milik pemberi sewa (perusahaan leasing). Akadnya dianggap sebagai akad sewa.Sedangkan bila pada masa akhir sewa pihak penyewa dapat melunasi cicilannya maka barang tersebut menjadi milik penyewa. Intinya, dalam financial lease terdapat dua proses akad sekaligus: sewa sekaligus beli. Dan inilah sebabnya mengapa leasing bentuk ini disebut sebagai sewa-beli.

\subsection{Ketentuan dan Aplikasi Mengenai Leasing}

Kegiatan leasing secara resmi diperbolehkan beroperasi di Indonesia setelah keluar surat kepu- tusan bersama antara Menteri Keuangan, Menteri Perindustrian, dan menteri perdagangan Nomor Kep. 122/MK/IV/2/1974 Nomor 32/M/SK/2/74 dan Nomor 30/Kbp/1/74 tanggal 1 Februari Tentang Perizinan Usaha Leasing di Indonesia. Wewenang untuk memberikan usaha leasing dikeluarkan oleh Menteri Keuangan berdasarkan Surat Keputusan Nomor 649/MK/IV/5/1974 tanggal 6 Mei 1974 yang mengatur mengenai ketentuan tata cara perizinan dan kegiatan usaha leasing di Indonesia. Perkembangan selanjutnya adalah dengan keluarnya Kebijaksanaan Deregulasi 20 Desember 1988 (Pakdes) yang mengatur tentang usaha leasing, merevisi ketentuan sebelumnya. Kemudian dalam Keppres No. 61 Tahun 1988 dan Keputusan Menteri Keuangan nomor 1251/KMK.013/1988 Tanggal 20 Desember 1988.Adapun landasan terkini adalah Keputusan Menteri Keuangan No. 1169/KMK.01/1991 tentang Kegiatan Sewa Guna Usaha (Leasing).

Pihak-Pihak yang terlibat dalam transaksi Leasing :

1) Lessor, merupakan perusahaan leasing yang membiayai keinginan nasabahnya untuk memperoleh barang modal.

2) Lessee, yaitu nasabah yang mengajukan permohonan leasing kepada lessor untuk memperoleh barang modal yang diinginkan.

3) Supplier, yaitu pedagang yang menyediakan barang yang akan dileasingkan sesuai perjanjian antara lessor dengan lease. Dalam hal ini supplier juga dapat dapat bertindak sebagai lessor.

4) Asuransi, merupakan perusahaan yang akan menanggung resiko terhadap perjanjian antara lessor dan lessee ( Kasmir, 2002 ).

Transaksi leasing yang biasa terjadi adalah sebagai berikut (misal leasing motor): seorang (misal fulan) datang ke lembaga pembiayaan dan ingin membeli motor secara kredit karena tak punya uang tunai. Lembaga pembiayaan membeli motor dari suplier/dealer motor, lalu dilakukan akad leasing antara lembaga pembiayaan dengan Fulan misalnya dalam jangka waktu tiga tahun. Dalam akad leasing itu terdapat fakta transaksi sebagai berikut: 
1) Lessor (lembaga pembiayaan) sepakat setelah motor itu dia beli dari dealer/suplier, dia sewakan kepada lessee selama jangka waktu tiga tahun.

2) Lessor sepakat setelah seluruh angsuran lunas dibayar dalam jangka waktu tiga tahun, lessee (Fulan) langsung memiliki motor tersebut.

3) Menurut fakta leasing yang ada, selama angsuran belum lunas dalam jangka tiga tahun itu motor tetap milik lessor.Keempat, motor itu dijadikan jaminan secara fudisia untuk leasing tersebut. Karena itu BPKB motor itu tetap berada di tangan lessor hingga seluruh angsuran lunas. Konsekuensinya jika lessee (Fulan) tidak sanggup membayar angsuran sampai lunas, motor akan ditarik oleh lessor dan dijual (Al Jawi, 2012 )

Adapun biaya-biaya yang dibebankan kepada lessee biasanya terdiri dari: 1) Biaya administrasi yang besarnya dihitung per tahun, 2) biaya material untuk perjanjian, 3) biaya bunga terhadap barang yang dileasingkan, 4) premi asuransi yang disetorkan kepada pihak asuransi.

Kegiatan-kegiatan yang dilakukan antara satu perusahaan leasing dengan perusahaan leasing lainya dapat berbeda. Di dalam surat keputusan menteri keuangan no.1169/KMK.01/1991 tanggal 21 november 1991, kegiatan leasing dapat dilakukan dengan dua cara,yaitu : Melakukan sewa guna usaha dengan hak opsi bagi lessee (finance lease); Melakukan sewa guna usaha dengan tanpa hak opsi bagi lessee (operating lease), kemudian dalam praktiknya transaksi finance leasing dibagi kedalam bentukbentuk sbb:

\section{Direct finance lease}

Transaksi ini dikenal dengan namatrue lease dimana didalam transaksi ini pihak lessor membeli barang modal atas permintaan lessee dan sekaligus menyewagunakan barang tersebut kepada lessee. Lessee dapat menentukan spesifikasi barang yang diinginkan termasuk penentuan harga dan suppliernya. Oleh kaena itu proses pembelian yang dilakukan lessor hanya untuk memenuhi kebutuhan pihak lessee.

\section{Sales dan lease back}

Proses ini dilkukan dimana pihak lessee menjual barang modalnya kepada lessor untuk dilakukan kontrak sewa guna usaha atas barang tersebut.antara lessee dan lessor.metode ini biasanya digunaka untuk menambah modal kerja pihak lessee. Sedangkan operating lease dimana pihak lessor sengaja membeli barang modal untuk kemudian dileasekan kepada pihak lessee.biaya yang dikenakan terhadap lessee adalah biaya yang dikenakan untuk memperoleh barang yang dibutuhkan oleh lessee berikut bunganya.

\subsection{Keuntungan dan Kelemahan Leasing}

Leasing sebagai alternative pembiayaan memiliki beberapa keuntungan dibandingkan dengan sumber pembiayaan lainnya, antara lain :

1) Menghemat modal, dengan adanya sistem pebiayaan dari leasing, maka lessee dapat mendapatkan dana untuk membeli barag modal hingga sebesar $100 \%$ dari harga barang tersebut seingga lessee dapat memanfaatkan modal yang sudah ada untuk keperluan lain.

2) Fleksibel merupakan ciri utama bagi kelebihan leasing dibandingkan kredit dari bank,baik fleksibel dari sisi struktur kontraknya, besarnya pembayaran rental, jangka waktu pembayaran,serta nilai residunya.

3) Dokumentasi SederhanaLeasing biasanya menggunakan dokumentasi yang sudah standar. hal ini menjadikan lessee lebih simple dalam melakukan transaksi leasing.

4) Pembiayaan proyek berskala besar.Adanya keengganan untuk memikul resiko investasi dalam pembiayaan yang sering kali menjadi masalah diantara pembarian dana,biasanya dapat diatasi melalui perusahaan leasing sepanjang tersedianya suatu jaminan penuh yang dapat diterima serta kemudahan untuk menguasai barang yang dibiayai apabila terjadi suatu kelalaian. Kelima, Cara memperoleh barang modal dipermudah, Mengurangi 
resiko inflasi dan terlindung dari resiko keusangan atau kemajuan tekhnologi.

Dengan memanfaatkan leasing, lessee dapat terhindar dari risiko akibat barang yang disewa tersebut mengalami ketinggalan model dan tekhnologi. Dalam suatu kontrak leasing,objek leasing sering dimasukan dalam perjanjian bahwa barang yang sedang disewa tersebut dapat ditukar dengan barang serupa yang lebih canggih paabila kemudian hari tedapat penemuan-penemuan yang lebih baik daripada produk barang yang sejenis.

Adapun kerugian dari leasing yaitu Leasing tidak menguntungkan dalam hal kelebihan uang tunai, leasing menghilangkan kebanggan pemilik, leasing mungkin memerlukan biaya yang lebih besar dari pada dengan cara lain dan mungkin menimbulakan kehilangan atas nilai sisa dari barang modal.

\subsection{Tinjauan Hukum Leasing Menurut Syara}

(Antonio, 2001)

Jenis Operating Lease atau dalam istilah muamalah "Ijarah", dibolehkan oleh syara' dengan dasar hukum:

Pertama, Al-Qur'an : QS. Al-Baqarah 233

Dan jika kamu ingin anakmu disusukan oleh orang lain, Maka tidak ada dosa bagimu apabila kamu memberikan pembayaran menurut yang patut. bertakwalah kamu kepada Allah dan ketahuilah bahwa Allah Maha melihat apa yang kamu kerjakan. (QS.Al-Baqarah: 233)

Dalil dari ayat tersebut di atas adalah ungkapan "apabila kamu memberikan pembayaran yang patut". Ungkapan tersebut menunjukkan adanya jasa yang diberikan berkat kewajiban membayar upah (fee) secara patut. Dalam hal ini termasuk didalamnya jasa penyewaan atau leasing (Ramli, 2005)

Kedua, Hadits

Diriwayatkan dari Ibnu Abbas bahwa Rasulullah saw bersabda, "Berbekamlah kamu, kemudian berilah olehmu upahnya kepada tukang bekam itu (HR. Bukhari Muslim)

Ketiga, Ijma'
Pakar-pakar keilmuan dan cendikiawan sepanjang sejarah diseluruh negeri telah sepakat akan legitimasi ijarah (Mugni Ibnu Qudamah)

Adapun mengenai jenis Financial Leasing, terdapat beberapa fakta yang menunjukkan keharaman transaksi ini, yaitu:

1) Dalam leasing terdapat penggabungan dua akad, yaitu sewa menyewa dan jual beli, menjadi satu akad (akad leasing).Padahal syara' telah melarang penggabungan akad menjadi satu akad. Ibnu Mas'ud RA:

"Nabi SAW melarang dua kesepakatan dalam satu kesepakatan (Shafqatain fi shafqatin wahidah)" (HR. Ahmad, Al Musnad, I/398).

Menurut Imam Taqiyuddin an Nabhani hadits ini melarang adanya dua akad dalam satu akad, misalnya menggabungkan dua akad jual beli menjadi satu akad, atau akad jual beli digabung dengan akad ijarah.

2) Dalam akad leasing biasanya terdapat bunga.Maka harga sewa yang dibayar per bulan oleh lesse bisa jadi dengan jumlah tetap (tanpa bunga), namun bisa jadi harga sewanya berubah-ubah sesuai dengan suku bunga pinjaman. Maka leasing dengan bunga seperti ini hukumnya haram, karena bunga termasuk riba (QS Al Baqarah [2] : 275 )

3) Dalam akad leasing terjadi akad jaminan yang tidak sah, yaitu menjaminkan barang yang sedang menjadi obyek jual beli. Imam Ibnu Hajar Al-Haitami berkata, "Tidak boleh jual beli dengan syarat menjaminkan barang yang dibeli.: (Al Fatawa al Fiqhiyah al Kubra, 2/287). Imam Ibnu Hazm berkata," Tidak boleh menjual suatu barang dengan syarat menjadikan barang itu sebagai jaminan atas harganya. Kalau jual beli sudah terlanjur terjadi, harus dibatalkan." (Al Muhalla, 3/437). Dalam hadits juga disebutkan:

Tidak halal salaf dan jual beli, tidak halal dua syarat dalam satu jual beli, tidak halal keuntungan selama (barang) belum didalam tanggungan dan tidak halal menjual apa yang bukan milikmu (HR. an-Nasa'i, atTirmidzi dan ad-Daruquthni) 
Berdasarkan tiga alasan di atas, maka leasing dengan hak opsi (finance lease), atau yang dikenal dengan sebutan leasing saja, hukumnya haram.

\subsection{Beberapa Persoalan dalam Leasing (Sewa- Beli)}

Merujuk pada kenyataan di atas, nampak bahwa dalam sewa-beli terdapat dua bentuk muamalah yang berbeda dalam satu proses yang bersamaan. Sewa sekaligus beli. Sampai di sini terdapat minimal dua persoalan yang memerlukan kajian, yaitu perbedaan sewa dan beli, serta kedudukan dua akad sekaligus dalam suatu proses muamalah.

Pertama, perbedaan sewa dan beli. Dalam hukum muamalah Islam sangat berbeda antara sewa dengan beli.Sewa (ijarah) merupakan suatu akad untuk mendapatkan suatu manfaat dari barang, jasa, ataupun orang dengan adanya kompensasi tertentu, biasanya berupa uang ('aqdun 'alal manfaat bi 'iwadh).Jadi, pihak penyewa mendapatkan hanya manfaat yang dikandung oleh barang yang disewanya.Adapun barangnya itu sendiri tetap merupakan hak milik pihak pemberi sewa.

Hal ini berbeda sekali dengan jual beli. Secara syar'iy, jual-beli (al bai') merupakan mubadalatu malin bi malin tamlikan wa tamallukan 'ala sabilit taradhi, yaitu pertukaran antara suatu barang dengan barang lain (termasuk uang) untuk pertukaran kepemilikan di atas dasar saling meridloi satu sama lain. Berdasarkan hal ini, barang dari pihak penjual akan menjadi milik dari pihak pembeli. Sebaliknya, uang atau barang (bila barter) dari pihak pembeli akan langsung menjadi milik pihak penjual. Proses jual-beli ini, tentu saja, dapat kontan dan bisa pula dilakukan dengan cicilan (kredit). Jelaslah, perbedaan mendasar antara sewa dengan beli terletak pada siapa yang berhak memiliki barang pada akhir masa transaksi.Dengan demikian, akad yang terjadi antara sewa sangat berbeda dengan akad pada jual-beli.Akad sewa berkonsekuensi pada tetap dimilikinya barang oleh pihak pemilik barang, sedangkan pihak penyewa hanya boleh memanfaatkan barang tersebut selama masa
penyewaan.Sedangkan akad jual-beli berujung pada pertukaran kepemilikan dari penjual ke pembeli dan dari pembeli ke penjual.

Kedua, Rasulullah SAW melarang dua akad berbeda terjadi dalam satu aktivitas muamalah. "Rasulullah SAW melarang (kaum muslimin) dua akad dalam suatu proses akad tertentu, " demikian diriwayatkan oleh Imam Ahmad tentang larangan Rasulullah SAW. Hadits ini maksudnya adalah tidak boleh seseorang melakukan dua akad berbeda dalam suatu proses muamalah tertentu. Tidak boleh, misalnya, seseorang menyatakan 'Saya menjual rumah saya ini kepada Anda dengan syarat Anda menjual rumah Anda yang di Puncak pada saya', 'Saya menjual perusahaan ini pada Anda dengan catatan Anda menikahkan putri Anda kepada saya', atau 'Saya menjual barang ini dengan harga 10 juta rupiah pada Anda dengan cicilan selama 2 tahun, tetapi bila di tengah jalan Anda tidak dapat melunasinya maka barang tersebut tetap menjadi milik saya dan uang yang telah Anda berikan dianggap sebagai sewa barang selama Anda menggunakannya.' Di dalam muamalah tadi terdapat dua akad sekaligus, menjual rumahnya sekaligus membeli rumah pembeli rumahnya dalam satu akad, menjual perusahaan sekaligus menikahi putri pembeli perusahaannya dengan hanya satu akad, dan jual-beli sekaligus sewa dalam satu akad tertentu.Semua ini bertentangan dengan sikap Rasulullah SAW tadi.

Berdasarkan hal ini nampaklah bahwa dalam muamalah financial leasing (yang secara umum dikenal dengan istilah 'leasing' saja) terdapat dua akad sekaligus dalam satu proses muamalah tertentu.Dan hal ini tidak sesuai dengan titah Rasulullah SAW.Padahal, dalam syariat Islam, bila akad yang terjadi sewa maka tetap berlaku sewa sampai batas akhir waktu penyewaan. Demikian pula, suatu akad jual-beli tetap sebagai jual beli.Andaikan jual-beli itu dilakukan dengan mencicil dan pihak pembeli belum dapat melunasi seluruh utang pembeliannya pada waktu yang telah disepakati, akad tersebut tetap jualbeli dan tidak dapat dialihkan menjadi akad apapun, termasuk diubah menjadi akad sewa. 
Bila dilihat dari realitasnya, muamalah jenis ini nampak mengunggulkan pemberi sewa (perusahaan leasing) dibandingkan dengan penyewa. Terlebih-lebih bila pihak pembeli merasa mencicil barang dengan harga 'pembelian'. Di tegah jalan, karena sesuatu hal, ia tidak mampu melunasinya. Akhirnya, barang yang diangankan untuk dimilikinya pada akhir cicilan nanti harus dikembalikan, dan ia hanya menyewa saja. Padahal, tentu saja, harga sewa logisnya lebih kecil dibandingkan dengan harga beli dengan cicilan.Satu hal lagi, persoalan leasing menjadi bertambah bila dalam cicilannya itu melibatkan riba (bunga). Sebab, Allah SWT memfirmankan : "Dan Allah telah menghalalkan jual beli serta mengharamkan seluruh riba" (QS. Al Baqarah [2] : 275).

\subsection{Solusi Alternatif}

Allah SWT telah menurunkan aturan yang memenuhi rasa keadilan manusia.Kaitannya dengan jual-beli dengan kredit, syariat Islam telah menggariskan apa yang disebut dengan $B a i$ Bitsaman Ajil (BBA). Bai' Bitsaman Ajil merupakan suatu proses perjanjian jual untuk barang tertentu antara pemilik dan pembeli, dimana pemilik barang akan menyerahkan barang seketika, sedangkan pembayaran dilakukan dengan cicilan dalam jangka waktu yang disepakati bersama. Secara ringkas, penjual dan pembeli menyepakati total harga barang tersebut, lama waktu pembayarannya, dan pembayaran tiap bulannya tanpa disertai bunga.

Sejak terjadi transaksi, barang tersebut resmi menjadi milik pembeli, hanya saja ia menanggung hutang seharga barang tersebut kepada pihak penjual. Untuk berjaga-jaga, dapat ditentukan adanya barang jaminan, termasuk barang yang diperjualbelikan tersebut. Bila pihak pembeli tidak dapat memenuhi kewajiban hutangnya dalam waktu yang disepakati tidak dilakukan penentuan harga ulang (repricing) ataupun pemberian sanksi.Salah satu jalan yang ditempuh adalah barang tadi (bila sebagai jaminan) dijual.Hasilnya, sebagian digunakan untuk melunasi sisa hutangnya dan, bila ada, sisanya diberikan kepada pihak pembeli.
Beberapa aturan Allah SWT menegaskan hal ini, diantaranya:

1) Firman Allah SWT: "Dan Allah menghalalkan jual beli dan mengharamkan riba" (QS. Al Baqarah [2] : 275). Dalam ayat ini kata Al Bai' bersifat umum.Artinya semua jual beli hukum asalnya halal kecuali ada nash-nash yang menjelaskan keharamannya.

2) Imam Bukhari, Muslim, dan Nasai meriwayatkan bahwa Rasulullah SAW pernah membeli bahan makanan dari seorang Yahudi dengan hutang dan beliau memberikan baju besinya sebagai jaminan.

Oleh karena itu ringkasnya, ada beberapa hal dalam leasing yang tidak sesuai dengan syari'at Islam. Oleh karena itu, perlu ada muamalah alternatif yang manfaat dan kegunaannya sama, serta legal menurut syari'at Islam. Alternatif dimaksud adalah al bai' bid dain (jual-beli dengan hutang) yang salah satu turunannya adalah bai' bitsaman ajil.

\subsection{Al-Ijarah Al-Muntahia Bit-Tamlik sebagai Alternatif Leasing}

Transaksi yang disebut dengan al-ijaroh almuntahia bit-tamlilk (IMB)adalah sejenis perpaduan antara kontrak jual beli dan sewa atau lebih tepatnya akad sewa yang diakhiri dengan kepemilikan barang ditangan sipenyewa. Sifat pemindahan kepemilikan ini pula yang membedakan dengan ijarah biasa (Antonio, 2001 )

Ijarah Muntahiyah Bittamlik (financial lease with purchase option) adalah transaksi ijarah yang diikuti perpindahan hak kepemilikan atas barang itu sendiri.IMBT di dalam Fatwa MUI nomor: 27/DSN-MUI/III/2002 diartikan sebagai perjanjian sewa-menyewa yang disertai dengan opsi pemindahan hak milik atas benda yang disewa, kepada Penyewa, setelah selesai masa aqad ijarah. Transaksi IMBT merupakan pengembangan transaksi iajrah untuk mengakomodasi kebutuhan masyarakat, karena IMBT merupakan pengembangan transaksi ijarah, maka ketentuannya mengikuti ketentuan ijarah. Rukun Ijarah Muntahia bit-Tamlik meliputi penyewa (musta'jir), pemberi sewa (mu'ajir), objek sewa (ma'jur), harga sewa (ujrah), man- 
faat sewa (manfa'ah) dan ijab qabul (sighat) (Wiyono, 2005 ).

Adapun proses perpindahan kepemilikan objek dalam transaksi IMB secara umum dapat dilakukan dengan cara sebagai berikut:

1) Hibah yakni transaksi ijarah yang diakhiri dengan perpindahan kepemilikan barang secara hibah dari pemilik objek sewa kepada penyewa. Pilihan ini diambil bila kemampuan finansial penyewa untuk membayar sewa relatif lebih besar. Sehingga akumulasi sewa di akhir periode sewa sudah mencukupi untuk menutup harga beli barang dan margin laba yang ditetapkan oleh bank.

2) Janji untuk menjual yakni transaksi ijarah yang diikuti dengan janji menjual barang objek sewa dari pemilik objek sewa kepada penyewa dengan harga tertentu. Pilihan ini biasanya diambil bila kemampuan financial penyewa untuk membayar sewa relatif kecil. Karena sewa yang dibayarkan relatif kecil, maka akumulasi nilai sewa yang sudah dibayarkan sampai akhir periode sewa belum mencukupi harga beli barang tersebut dan margin laba yang ditetapkan oleh bank. Bila pihak penyewa ingin memiliki barang tersebut, maka ia harus membeli barang itu di akhir periode.

\section{Kesimpulan}

Konsep maqasid asy-syariah dalam mewujudkan kemaslahatan manusia yang berupa; agama, jiwa, akal, dan harta (Al-kulliyah alkhamsah), dimana inti dari konsep maqasid asysyariah adalah mencegah kerusakan dan mendatangkan kemanfaatan. Jenis Operating Lease atau dalam istilah muamalah "Ijarah", dibolehkan oleh syara', transaksi Leasing merupakan kegiatan pembiayaan dalam bentuk penyediaan barang modal (misal mobil atau mesin pabrik) yang dibayar selama jangka waktu tertentu berdasarkan pembayaran secara berkala. Bentuk kegiatan leasing dibedakan menjadi dua, yaitu operating lease (yakni sewa beli tanpa hak opsi) dan financial lease (sewa beli dengan hak opsi. Operating lease dalam istilah fiqih sama dengan ijarah, sedangkan praktik financial lease yang sudah disesuaikan dengan kriteria syara' dinamakan al-Ijarah Muntahia bit Tamlik (IMBT) dan hukumnya halal. Sedangkan berdasarkan praktik dan realitanya dalam kehidupan seharihari, financial lease menunjukkan keharaman transaksi, dan para ulama sepakat ini ada ada dalam praktik financial lease (leasing konvensional).

\section{Ucapan Terimakasih}

Terimakasih kami haturkan kepada STIE AAS Surakarta atas supportnya hingga selesai dan terbitnya tulisan ini.

\section{Daftar Pustaka}

Al Jawi, M S. (2012), Hukum Leasing: Media Umat edisi 77

Antonio, M.S. (2001), Bank Syariah dari Teori ke Praktik, Jakarta: Gema Insani

Cahyani, D. I., \& Sumadi, S. (2015). Alternatif Sistem Ekonomi Islam Untuk Indonesia Yang Lebih Sejahtera. Jurnal Ilmiah Ekonomi Islam, 1(02).

Karim, A. (2003) Bank Islam: Analisis Fiqih dan Keuangan. IIIT Indonesia, Jakarta

Kasmir (2002), Bank dan Lembaga Keuangan Lainnya, PT RajaGrafindo Persada, Jakarta

Kurnia, MR.(2007). Hukum Seputar Leasing, Media Ummat

Nasution, M. (2006). Akuntansi Guna Usaha (Leasing) Menurut Pernyataan SAK No. 30.

Nur, A. W. (2007). Sistem Pembiayaan Leasing di Perbankan Syariah. La_Riba, 1(2), 169186.

Ramli, H. (2005). Briefcase Books Edukasi Profesional Syariah Teori Dasar Akuntansi Syariah. Jakarta; Renaisan

Siamat, D. (1995), Manajemen Lembaga Keuangan, Jakarta: Intermedia

Sukardi. (2005) Metode Penelitian Pendidikan: Kompetensi dan Prakteknya, Jakarta: Bumi Aksara

Sumadi, S. (2017). Kasus Pencucian Uang Dalam Tinjauan Sistem Ekonomi Syari'ah. Jurnal Ilmiah Ekonomi Islam, 3(03), 186192. 
Jurnal Ilmiah Ekonomi Islam, 4(02), 2018, 135

Wiyono, S. (2005). Cara Mudah Memahami PSAK Dan PAPSI. Grasindo. Akuntansi Perbankan Syariah: Berdasarkan 